\title{
Izvor poimenovanj za orodja in hišne pripomočke $v$ terskem narečju
}

\author{
Janoš Ježovnik
}

Cobiss: 1.01

V prispevku so predstavljena narečna poimenovanja orodij in hišnih pripomočkov, razstavljenih v etnografskem muzeju v kraju Bardo/Lusevera v Terski dolini. Opredeljena so $\mathrm{z}$ vidika izvora, in sicer so lahko neprevzeta (tvorjena ali netvorjena) ali prevzeta (zgodaj ali pozno). V naboru močno prevladuje prevzeto besedje, ki izpodriva tudi starejša neprevzeta poimenovanja.

Ključne besede: tersko narečje, narečno poimenovanje, jezik v stiku, prevzeto besedje, etimologija

\section{The Origin of Terms for Tools and Household Instruments in the Terski} Dialect

This article presents dialect names for tools and instruments displayed in the ethnographic museum in the village of Lusevera (Sln. Bardo) in the Torre Valley. The names are defined according to their origin; they may be native (root or compound) or loanwords (borrowed early or late). The latter represent a large majority of the words analyzed and are replacing old native names as well.

Key-words: Terski dialect, dialect name, language contact, loanwords

\section{Geografska umestitev in zgodovinski pregled območja}

Občina Bardo/Lusevera se nahaja v zgornji dolini reke Ter in njenih zgornjih pritokov v Videmski pokrajini Furlanije - Julijske krajine v Italiji. Poleg istoimenske vasi obsega še naselja Brieh/Pers, Mužac/Musi, Njivica/Vedronza, Podbardo/ Cesariis, Sedlišča/Micottis, Ter/Pradielis in Zavarh/Villanova delle Grotte. Kot večina visokogorskih občin se tudi Bardo v zadnjih desetletjih spopada $\mathrm{z}$ upadom prebivalstva, v prvi vrsti posledico povojnih (začasnih in stalnih) ekonomskih migracij, trend pa se je po uničujočih potresih spomladi in jeseni leta 1976 in z upadom podeželske kulture še okrepil s preseljevanjem v bližnja mestna središča. Če je občina na svojem demografskem višku leta 1921 štela 3232 prebivalcev, se je število do leta 1971 zmanjšalo na 1910, po podatkih z začetka leta 2014 pa tam prebiva 674 prebivalcev. ${ }^{1}$

1 Podatki so bili pridobljeni s pomočjo spletnega portala Narodnega inštituta za statistiko Republike Italije (Istituto nazionale di statistica) na naslovu http://www.istat.it. Prim. tudi Ruttar 2006. 
Slovani so območje Furlanije poselili v 7. in 8. stoletju, in sicer tako z vzhoda (preko Soče) kot s severa (s Koroške preko Kanalske doline). Območje je bilo že od časov pokristjanjevanja pod vplivom Oglejskega patriarhata, leta 1077 pa mu je po ukazu cesarja Henrika IV. pripadla tudi posvetna oblast nad tem ozemljem. Približno iz tistega obdobja, iz leta 1150, je prva omemba vasi Bardo (Marušič 2006: 56-57). Po porazu patriarhata proti Beneški republiki leta 1420 je upravljanje ozemlja prešlo pod njeno upravo. Pod Republiko sv. Marka se je za območje s slovensko poselitvijo uveljavilo poimenovanje Schiavonia Veneta, tj. Beneška Slovenija (Kos idr.: 14). Tamkajšnji prebivalci so uživali visoko stopnjo avtonomije in bili v zameno za varovanje meje oproščeni plačevanja davkov (Kacin Wohinz - Pirjevec: 17), do neke mere so bili avtonomni tudi pri izvajanju sodne oblasti. Leta 1797 je po porazu proti Napoleonu in padcu Beneške republike ozemlje Furlanije in Beneške Slovenije pripadlo Habsburški monarhiji, med letoma 1806 in 1814 pa je bilo del kratkožive marionetne države pod Napoleonovim vplivom, Italijanskega kraljestva. Ko je zatem spet pripadlo Habsburški monarhiji, ta prebivalcev ni obravnavala po posebnih merilih, temveč jih je obremenila z navadnimi državljanskimi dolžnostmi, kar je med njimi vzbudilo nezadovoljstvo nad novo oblastjo. Po porazu Avstrije proti Prusiji in na novo združeni Italiji leta 1866 so slednji pripadla tudi ozemlja s slovenskim prebivalstvom in to je s spominom na prejšnjo beneško oblast in stare privilegije na plebiscitu rado potrdilo aneksijo.

Pritiski oblasti so v času od priključitve Italiji povzročili načrtno asimilacijo slovensko govorečega prebivalstva v Beneški Sloveniji. Nova Italija je namreč težila $\mathrm{k}$ oblikovanju centralistične, narodno enotne države, $\mathrm{v}$ kateri ni bilo prostora za etnične manjšine (Kacin Wohinz - Pirjevec: 17). Zapovedana je bila raba italijanskega jezika, lokalno slovensko govoreče prebivalstvo pa je bilo podvrženo odkriti asimilaciji: časopis Giornale di Udine je tako dne 22.11. 1866 na prvi strani zapisal: »Questi slavi bisogna eliminarli!« (Te Slovane je treba odstraniti!) Domača govorica se je bila prisiljena umakniti italijanščini tudi $\mathrm{v}$ poluradni rabi $\mathrm{v}$ šoli in cerkvi - v Bardu so bile pridige v slovenščini ukinjene leta 1870 (Marušič 2006: 60 ) - in ostala je omejena le še na zasebno rabo. Intenzivni italijanizaciji je bilo slovensko prebivalstvo izpostavljeno zlasti $\mathrm{v}$ začetku 20. stoletja $\mathrm{v}$ času vzpona in vladavine fašizma, tudi po 2 . svetovni vojni pa je bil asimilacijski pritisk zelo močan: formalno preko nepriznavanja slovenske prisotnosti in uradne zaščite slovenske skupnosti s strani uradnih oblasti, ${ }^{2}$ neformalno pa $\mathrm{z}$ dejanskim pritiskom različnih posameznikov in organizacij, med katerimi je najbolj razvpita tajna paravojaška organizacija Gladio. K asimilacijskim težnjam so pripomogli še migracije, preseljevanje $v$ mestna središča in razmah sodobnih medijev, ki praviloma oddajajo $\mathrm{v}$ jeziku večinskega prebivalstva, tj. italijanščini.

2 Slovensko govoreče prebivalstvo v Videmski pokrajini je bilo na primer šele leta $2001 \mathrm{z}$ državnim zakonom št. 38 priznano kot del slovenske jezikovne manjšine v Italiji. 


\section{Jezikovno stanje}

\subsection{Umestitev narečja}

Tersko narečje se glede na starejše jezikovne spremembe ${ }^{3}$ uvršča $v$ beneško-kraško narečno ploskev severozahodnih slovenskih narečij, v katero spadajo še nadiško, briško in kraško narečje $\mathrm{z}$ banjškim podnarečjem. Znotraj te ga skupaj z nadiškim narečjem ločimo od ostalih, saj sta obe narečji ohranili kolikostna in tonemska nasprotja na dolgih zlogih ter izkazujeta popolni sovpad ${ }^{*} \bar{e} /{ }^{*} \grave{e}_{-}={ }^{*} \bar{e} /{ }^{*} \grave{e}-,{ }^{*} \bar{g} /{ }^{*} \grave{Q}-{ }^{*}{ }^{*} \dot{o}-$. Obe narečji načeloma ohranjata issln. naglasno mesto v tipih *ženà, *kozà *maglà, tersko narečje pa je v razmerju do nadiškega bolj inovativno po naglasnih spremembah v tipih issln. *okô, *večêr $>$ ter. ó:ko, vé:čer (v pretežnem delu narečju z izjemo skrajno vzhodnega dela); issln. *pàlica, *zíma $>$ nespl. ter. pa(:)'lica, zi(:)'ma (zlasti v vzhodnem delu narečja).

Za tersko narečje so značilni poseben odraz $\dot{c}<$ psl. *t́t (zvon'çić 'zvonček', brú:șić 'brus'), prehod $-m>-n$ (diẹlan, viẹn), vokalizacija vsakršnega polglasnika (Bá:rdo, șà:rp, povè̀rak), prehod $* \dot{l}>j$ (çúrce, veșeje), nesplošno terska (značilna za zahodni in južni del narečja) pa je onemitev glasu $g$ (zbirka mašnih beril Boava besieda, vendar bùox); najti pa ga je v nekaterih mlajših prevzetih besedah (gérrç, Red gé:rza $\leftarrow$ ben. it. garze) (Šekli 2006b; Ramovš 1935: 51-54; Zuljan Kumer 2010).

$\mathrm{V}$ terskem narečju poteka sovpad sičnikov in šumevcev $[c]$ in $[c],[s]$ in $[\check{s}]$ ter $[z]$ in $[z]$. Najverjetneje gre za vpliv stičnih romanskih idiomov, tj. furlanščine in beneškega narečja italijanščine, ki poznata le opozicijo $/ c|:| \check{c} / ; / s /$ in $/ z /$ šumniških ustreznikov nimata, njuna realizacija pa je nekoliko palatalna. Pojav je najbolj razvit ravno v zahodnem delu terskega narečja. Čeprav gre za isto težnjo kot pri t. i. slekanju v baškem podnarečju tolminskega narečja, $v$ tem delu terskega narečja

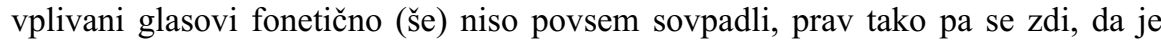
refleks, h kateremu težijo, drugačen od refleksa sovpada sičnikov in šumevcev pri slekanju. Glasovi v sovpadanju sicer težijo k nekoliko palataliziranemu sičniškemu izgovoru, vendar je razpon možnih realizacij zelo širok. Tako se lahko izvorni sičnik realizira povsem sičniško, a tudi povsem šumniško, obratno pa velja tudi za izvorni šumevec, pri čemer se zdi, da realizacija ni vezana na glasovno okolje (govorci foneme npr. drugače realizirajo ob ponovnem izgovoru istih besednih oblik). Pri tem govorec glasov ne razloči oziroma ju občuti kot isti fonem. S pojavom se vzpostavlja celo tonemski minimalni par [nùọ̣] 'nos' : [nuọ́s] 'nož'.${ }^{4}$ Pojav je treba

3 Slovenska narečja se glede na starejše jezikovne spremembe razvršča na narečne ploskve po naslednjih merilih: (1) prisotnost/odsotnost zgodnjega raznosnjenja issln. ${ }^{*} e, *_{Q}(>$ SZ sln. ${ }^{*} e,{ }^{*}:$ JV $\left.\operatorname{sln} .{ }^{*} e,{ }^{*}\right)$ ); (2) s prejšnjim pojavom povezani (Rigler 2001: 16) način diftongizacije issln. $*_{\bar{e}},{ }^{*} \bar{o}\left(>\mathrm{SZ} \operatorname{sln} . *_{i e},{ }^{*} u o\right.$ : JV sln. $\left.{ }^{*} e i, *_{o u}\right)$; (3) prisotnost/odsotnost in čas daljšanja kratkoakutiranih zložnikov v nezadnjem besednem zlogu (issln. $* \grave{V} V$ $>\mathrm{JZ} \operatorname{sln} . * \dot{V} V$ (zgodnje daljšanje v 13.-14. stol.) : $\mathrm{S}$ in zah. $\mathrm{V} \operatorname{sln} . * \dot{V} V / * \grave{V} V V$ (pozno daljšanje v 16. stol.) : vzh. V sln. *VVV); (4) kakovost odraza issln. *j (> J in Z $\operatorname{sln} . * a: \mathrm{S}$ in V sln. *e); (5) način sovpada različnih $e$-jevskih in $o$-jevskih samoglasnikov. Na osnovi mlajših jezikovnih pojavov se narečja uvrščajo v narečne skupine, pri čemer so lahko glede na izvor precej raznorodna (po Šekli 2009: 294-295).

4 Zaradi izgube fonološkega kontrasta in razlik v fonetični realizaciji so omenjeni fonemi v nadaljevanju prispevka dosledno označeni s pikico pod znakom, tj. kot $c, s$ in $z$. Takšno 
še raziskati, zlasti natančneje določiti kvaliteto refleksov sovpada in izključiti morebitni vpliv glasovnega okolja na razlike $\mathrm{v}$ fonetični realizaciji; vlogo bi lahko imel tudi čas prevzema pri prevzetih besedah. Na fonema $/ \dot{c} /$ in $/ \xi \dot{z} /$ pojav, verjetno zaradi njune izrazito palatalne narave, ne vpliva, o vplivu na obrobna fonema $/ \zeta /$ in $/ \breve{\zeta} /$, ki nastopata izključno $\mathrm{v}$ prevzetih besedah, pa zaradi premajhnega obsega gradiva za zdaj ne moremo sklepati.

\subsection{Idiomi v stiku}

Območje današnje Furlanije - Julijske krajine je bilo v preteklosti izrazito jezikovno pestro, prebivalci pa so poleg maternega pogosto govorili tudi jezik drugače govorečih sosedov. Pri tem jezik ni imel izrazite identifikacijske vloge, temveč je bolj prišla do izraza zavest o lokalni pripadnosti. »Deželni patriotizem je namreč presegal ne le jezikovne, temveč tudi domnevne etnične razlike. Zaobjemal je celotno prebivalstvo dežele, in sicer ne glede na materni jezik in domnevni etnični izvor.« (Makuc 2013)

Slovensko govoreče prebivalstvo Terskih dolin je bilo v obdobju po stalni poselitvi v stiku s starejšimi razvojnimi stopnjami nemščine (srednjo visoko nemščino), ki je bila poleg latinščine uradovalni jezik Oglejskega patriarhata. Ker pa je bila nemščina kljub germanski usmerjenosti patriarhata med ljudstvom malo rabljena, smemo domnevati, da stik ni bil intenziven; starejši germanizmi (iz stare visoke nemščine) so bili prevzeti že prej, na kar kaže med drugim razširjenost tega besedja po širšem slovenskem in celo slovanskem prostoru.

Zgodovinsko so bili tamkajšnji govorci slovenščine v najintenzivnejšem stiku s furlanščino, jezikom alpskoromanskega izvora, zato se ne čudimo medsebojnemu vplivu, ki se v obeh jezikih kaže na različnih ravneh (prim. Skubic 1997; 2006). Po priključitvi Beneški republiki leta 1420 dobi manjši vpliv tudi kolonialno beneško narečje (it. veneto coloniale) italijanščine, po priključitvi Italiji leta 1866 pa začne na veljavi preko lokalne uprave, šolstva in cerkvenih dejavnosti čedalje bolj pridobivati knjižna italijanščina.

Stik z osrednjeslovenskim prostorom zaradi že opisanih zgodovinskih okoliščn ni bil nikoli intenziven, vpliv slovenske kulture in slovenskega knjižnega jezika pa je bil tako rekoč ničen. Izjema so redki narodni buditelji, skoraj brez izjeme vsi duhovniki, Ivan Trinko (1863-1954), Anton Kofol (1889-1959), Jožef Kramar (1897-1974) idr., ki so s svojo dejavnostjo skrbeli tudi za širitev knjižnega jezika.

Za terske Slovence je torej od nekdaj značilna večjezičnost, saj govorci slovenskega narečja danes praviloma obvladajo tudi knjižno italijanščino, zlasti starejši pa tudi lokalno narečno varianto furlanščine, asimilacijski pritisk pa je pri njih povzročil diglosijo, tj. stanje, ko se $\mathrm{v}$ zasebnem in javnem govornem položaju neenakopravno izmenjujeta raznorodna koda ( $\mathrm{v}$ tem primeru narečna slovenščina kot zasebni in knjižna italijanščina kot javni kod). Čeprav je v zadnjem času asimilacijski pritisk na slovensko govoreče prebivalstvo upadel, pa je jezikovna zmožnost zlasti mlajših govorcev zelo nizka.

označevanje nakazuje sorodnost s slekanjem (označevanje s $\dot{c}, \dot{s}$ in $\dot{z}$ ), a hkrati odraža že navedene razlike. 


\section{Izvor poimenovanj za orodje in hišne pripomočke v terskem narečju}

V nadaljevanju je v luči opisane interakcije s stičnimi romanskimi idiomi navedeno in analizirano besedje, ki v terskem narečju poimenuje orodje in hišne pripomočke, zbrane in razstavljene kot del zbirke etnografskega muzeja v Bardu. ${ }^{5}$ Glede na izvor lahko obravnavano besedje razdelimo na neprevzeto in prevzeto. Neprevzeto besedje je podedovano iz praslovanščine ali je nastalo v eni od faz oblikovanja slovenščine iz pozne praslovanščine. Deli se lahko na netvorjeno, ki izkazuje odsotnost (s stališča narečja) produktivnih besedotvornih vzorcev, ali tvorjeno, ki izkazuje prisotnost produktivnih besedotvornih vzorcev.

Prevzeto besedje je lahko zgodaj prevzeto, $\mathrm{tj}$. prevzeto bodisi v pozni praslovanski dobi bodisi v poznejšem času pred intenzivnim stikom z romanskim adstratom, ali pozno prevzeto, tj. prevzeto $\mathrm{v}$ novejšem času zlasti iz furlanščine in kolonialnega beneškega narečja italijanščine, po letu 1866 tudi iz knjižne italijanščine.

\subsection{Merila določanja izvora pozno prevzetega besedja}

Pri določanju izvora pozno prevzetega besedja se upošteva naslednja merila (Šekli 2014: 300):

(a) besedoslovno (leksikološko) merilo: za isti pomen sorodni idiomi v stiku s slovenščino izkazujejo izvorno (korensko ali besedotvorno) različne lekseme (npr. ćandrè:ja 'stol' $\leftarrow$ furl. cja(n)drèe 'stol' : ben. it., knj. it. sedia 'stol');

(b) pomenoslovno (semantično) merilo: izvorno isti leksem ima v sorodnih idiomih v stiku s slovenščino različne pomene (npr. fal'çet 'kosa' $\leftarrow$ furl. falcet 'kosa' : knj. it. falcetto 'manjši srp');

(c) glasoslovno (fonetično-fonološko) merilo: izvorno isti leksem ima v različnih sorodnih idiomih v stiku s slovenščino različno glasovno podobo, ki je posledica divergentnih glasovnih sprememb njegove izhodiščne glasovne podobe (npr. brò:ka 'vrč za vino' $\leftarrow$ knj. it. brocca, ben. it. ( $\leftarrow$ knj. it.) broca : furl. brocje).

\subsubsection{Glasoslovna merila razločevanja med relevantnimi romanskimi idiomi}

Glasoslovna merila razločevanja med romanskimi idiomi, s katerimi je bilo v stiku tersko narečje slovenskega jezika (tj. furlanščina, beneško narečje italijanščine in knjižna italijanščina), so povzeta po Šekli 2013:301-310.

\section{(a) Odrazi, ki omogočajo razločevanje med vsemi tremi idiomi}

rom. *kl-, *gl-> furl. $k l-, g l-:$ ben. it. $\check{c}-, \breve{z}-:$ knj. it. $k j-, g j-$

5 Stalna zbirka je bila razstavljena leta 1980 in je od tedaj na ogled v nekdanji mlekarni v Bardu (Križnar 2006). Razstavljene predmete mi je prijazno opisala soproga idejnega snovalca razstave Viljema Černa, gospa Marisa Cher (roj. 1950), sicer domačinka iz Barda in rojena govorka narečja. 
(b) Odrazi, ki omogočajo razločevanje med furlanščino na eni in kolonialno beneško ter knjižno italijanščino na drugi strani

rom. * $p l-,{ }^{*} b l-,{ }^{*} f l->$ furl. $p l-, b l-, f l-:$ ben. it., knj. it. $p j-, b j-, f j-$

rom. ${ }^{*} t j,{ }^{*} d j>$ furl. $\check{c}, \breve{\zeta}:$ ben. it., knj. it. $c, 3$

rom. ${ }^{*} k a,{ }^{*} g a>$ furl. $\check{c} a, \stackrel{\zeta}{\zeta} a(>\check{c} a, \breve{\zeta} a)$ : ben. it., knj. it. $k a, g a$

rom. $*_{e} C C,{ }^{*} o C C>$ furl. je, $w a:$ ben. it., knj. it. $e, o$

rom. *e $C V$, * $o C V>$ furl. je, wa $(>-\bar{l},-\bar{u}):$ ben. it., knj. it. je, wo

(c) Odrazi, ki omogočajo razločevanje med kolonialno beneško italijanščino na eni ter furlanščino in knjižno italijanščino na drugi strani

rom. ${ }^{*} k E-,{ }^{*} g E->$ ben. it. $c, 3(>s, z)$ : furl., knj. it. $\check{c}, \breve{\zeta}$

rom. ${ }^{*} k j,{ }^{*} g j>$ ben. it. $c, z(>s, z)$ : furl., knj. it. $\check{c}, \check{z}$

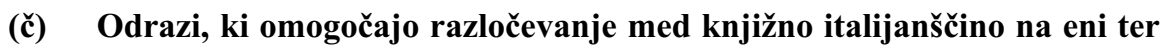
furlanščino in kolonialno beneško italijanščino na drugi strani

rom. ${ }^{*} V T V>$ knj. it. $V T V$ : furl., ben. it. $V D V$

rom. ${ }^{*} l j>$ knj. it. $l i l$ : furl., ben. it. $j$

Na najmlajše prevzeme izknjižne italijanščine kaže nadomeščanje knjižnoitalijanskih $s, z$ s slovenskima $s, z$. Pri nekoliko starejših prevzemih prihaja zaradi narečnih izgovornih značilnosti beneške italijanščine in furlanščine do substitucije $\mathrm{s}$ slovenskima $\check{s}, \check{z}$ (prim. tudi 2.1).

\subsection{Predstavitev narečnih poimenovanj}

\subsubsection{Načela predstavitve}

Narečna poimenovanja so predstavljena $\mathrm{v}$ obliki slovarskih sestavkov, oblikovanih po načelih nekaterih vidnejših strokovnih prispevkov $\mathrm{k}$ slovenskemu narečnemu slovaropisju (Weiss 1998; 2006; Kenda-Jež 2007). Sestavek tvorijo geselska glava ter oblikovni, razlagalni in dokumentarni razdelek. Geselska glava obsega poknjiženo iztočnico s pripadajočimi podatki o oblikovnih lastnostih besede ${ }^{6}$ ter narečno iztočnico v imenovalniku ednine. Oblikovni razdelek v lomljenem oklepaju navaja vse zapisane pregibne oblike besede in njihove morebitne glasovne različice. $\mathrm{V}$ razlagalnem delu je $\mathrm{v}$ pomenskih narekovajih narečna beseda razložena $\mathrm{s}$ knjižno ustreznico ali s pomensko razlago, če primerne ustreznice ni. Če je pomen ustrezno razviden že iz poknjižene iztočnice, je ta del izpuščen. Dokumentarni razdelek je razdeljen na dva dela, leksikološkega, ki ga uvaja znak $\square$, in etimološkega, ki ga uvaja znak $\mathbf{E}$. Prvi prinaša podatke o izpričanosti besed v Slovensko-nemškem slovarju Maksa Pleteršnika (v sestavku označen s Plet.), Slovarju slovenskega knjižnega jezika (SSKJ) ter slovarju terskega narečja Jana

6 Besednovrstno so vsa zapisana poimenovanja samostalniki, kar je zaradi narave predmeta raziskave, tj. poimenovanj materialne dediščine, razstavljene $\mathrm{v}$ okviru etnografske zbirke, razumljivo. Ker za vse lekseme niso zapisane ustrezne narečne oblike, so podatki o oblikovnih lastnostih pripisani poknjiženi iztočnici. 
Baudouina de Courtenayja (Spinozzi Monai 2009; v sestavku označen z BdC). ${ }^{7}$ Prav tako je $\mathrm{v}$ tem delu navedeno še narečno poimenovanje predmeta, kot je zapisano $\mathrm{v}$ neuradnem katalogu muzeja (Del Medico 2004; v sestavku označeno s kat.); krepko, če nastopa kot iztočnica, in navadno, če se pojavlja le v besedilu. Drugi del prinaša rekonstruirano in morfemsko segmentirano praslovansko podobo besed, kjer je mogoče, je podana tudi rekonstrukcija naglasnega stanja in umestitev v naglasni tip (označen v oklepaju) ${ }^{8}$ če ni posebej navedeno drugače, so etimološke osvetlitve

7 Izpričanost leksemov v naštetih slovarskih priročnikih je označena z znaki, navedenimi v razdelku Znaki in simboli. Če je leksem izpričan v vseh priročnikih ali pa ni izpričan v nobenem, stojita znaka + oziroma - samostojno. Če je v Spinozzi Monai 2009 leksem zapisan neupoštevajoč morfonološko-etimološko načelo zapisovanja (npr. klen nam. klin, nиоš nam. nuоž, stou nam. stol ipd.), je pri vnosu BdC neposredno navedeno geslo iz tega priročnika (prim. npr. iztočnice klin, nož in stol v 3.2.2.1).

8 Praslovanski naglasni tip predstavlja vzorec razvrstitve naglasnega mesta in različnih tonemov znotraj pregibalnih vzorcev pregibnih besednih vrst. V praslovanščini je smiselno razlikovati med naglasnimi tipi v oblikotvorju, ki jih je rekonstruiral Christian S. Stang (Stang 1957), in v besedotvorju, ki jih je rekonstruiral Vladimir A. Dybo (Dybo 1981, 2000; Dybo - Zamjatina - Nikolajev 1990, 1993). Prvi so značilni za glagolske in netvorjene imenske besedne vrste: psl. nagl. tip $\boldsymbol{a}$ - stalni staroakutski naglas na osnovi; psl. nagl. tip $\boldsymbol{b}$ - stalni naglas tipa novega akuta na prvem ali edinem zlogu končnice; psl. nagl. tip $\boldsymbol{c}$ - polarizirano premično naglasno mesto, tj. naglasno mesto na prvem ali zadnjem zlogu fonetične besede (v tem tipu razlikujemo fonološko naglašene in fonološko nenaglašene oblike - prve imajo stalno naglasno mesto na zadnjem ali edinem zlogu končnice, pri drugih pa je mesto naglasa odvisno od skladenjskega okolja, točneje od prisotnosti naslonk, ki so $\mathrm{v}$ tem nosilke starocirkumfleksnega naglasa; polnopomenska beseda je $\mathrm{v}$ fonološko nenaglašeni obliki torej fonetično naglašena le ob odsotnosti naslonk, in sicer s starim cirkumfleksom na prvem zlogu); navedenim nagl. tipom moskovska naglasoslovna šola pridaja še psl. nagl. tip $\boldsymbol{d}$, ki je značilen le za nekatere pregibalne vzorce (moška $o$-sklanjatev, $i$-sklanjatev, $u$-sklanjatev, soglasniška $s$-sklanjatev) - fonološko nenaglašene oblike I/Ted, nepremično naglasno mesto in tonem tipa novega akuta na prvem ali edinem zlogu končnice v ostalih sklonih (Dybo Zamjatina - Nikolajev 1990: 129-154). Poleg navedenih moskovska naglasoslovna šola dodaja še dva besedotvorno pogojena naglasna tipa (Dybo 2000: 98) z nepremičnim naglasnim mestom in tonemom tipa novega akuta na prvem zlogu, in sicer psl. nagl. tip $\boldsymbol{a}^{\prime}$, značilen za tvorjene samostalnike a-sklanjatve, izpeljane s priponskim obrazilom

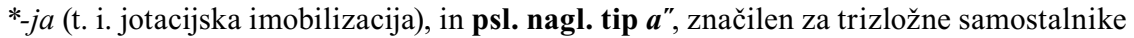
$a$-sklanjatve in moške $o$-sklanjatve, izpeljane iz sestavljenih glagolov s kvalitativnim prevojem $*_{e} \rightarrow *_{o}$ (t. i. prefiksalna imobilizacija). - Besedotvorni naglasni tipi so vzpostavljeni za izimenske besedne vrste, izpeljane s praslovanskimi produktivnimi priponskimi obrazili, ter glagolske sedanjiške in nedoločniške oblike z izjemo sedanjika, in sicer na podlagi oblikotvornega naglasnega tipa izpeljanke in vrste samoglasnika priponskega obrazila: psl. nagl. tip $\boldsymbol{A}$ - nepremično naglasno mesto in staroakutski tonem na besedotvorni podstavi (= psl. nagl. tip a); psl. nagl. tip $\boldsymbol{B}$ - nepremično naglasno mesto in tonem tipa novega akuta na prvem ali edinem zlogu končnice $(=$ psl. nagl. tip $b$ ); psl. nagl. tip $\boldsymbol{C}$ - polarizirano premično naglasno mesto (= psl. nagl. tip c); psl. nagl. tip $\boldsymbol{D}$ - stalni naglas na polglasniku priponskega obrazila, psl. nagl. tip $\boldsymbol{E}$ - stalni naglas tipa novega akuta na kratkem samoglasniku priponskega obrazila; psl. nagl. tip $\boldsymbol{F}$ - stalni staroakutski naglas na dolgem samoglasniku priponskega obrazila 
- $\quad$ povzete po relevantnih etimoloških priročnikih slovenskega jezika (Bezlaj 1976표 2007, Snoj 2009), rekonstrukcije naglasnega stanja zlasti pri tvorjenem besedju pa N so delo avtorja. Pri prevzetih besedah je naveden tudi vir prevzema, v pomenskih - narekovajih pa še navedba pomena izhodiščne besede, povzeta po relevantnih slovarskih priročnikih (če ni drugače označeno, Boerio za ben. it., Pirona za furl., Zingarelli in Šlenc 2008 za knj. it.).

Iz obravnave so izločena nekatera citatna poimenovanja, npr. pjà:l:a $a$ it. pialla 'oblič', podana v italijanščini, ko se informatorka ni spomnila narečnega poimenovanja, $\mathrm{v}$ redkih primerih pa kot posledica nepoznavanja razstavnih eksponatov.

\section{Kratice in krajšave}

D dajalnik

ed ednina

I imenovalnik

kat. muzejski katalog

M mestnik

m moški spol

mn množina

$\mathrm{O}$ orodnik

$\mathrm{R}$ rodilnik

S srednji spol

$\mathrm{T}$ tožilnik

Ž ženski spol

\section{Znaki in simboli}

- $\emptyset$ ničta končnica

- uvaja narečno iztočnico

〈〉 oklepa oblikovni razdelek

'xxx' pomenska razlaga

L uvaja leksikološki del dokumentarnega razdelka

E uvaja etimološki del dokumentarnega razdelka

+ V slovarskem priročniku je enaka iztočnica

- V slovarskem priročniku ni enake iztočnice

$\sim \quad$ iztočnici se pomensko ne prekrivata

$\rightarrow \quad$ uvaja podoben leksem $\mathrm{z}$ enakim pomenom

$\leftarrow \quad$ označuje smer prevzema

$<\quad$ nastalo po regularnem jezikovnem razvoju iz

$\leq \quad$ nastalo po neregularnem jezikovnem razvoju iz

(glede na naglasni tip besedotvorne podstave izpeljanke ločimo dva podtipa, in sicer psl. nagl. tip $F_{1}$, če se podstava uvršča v psl. nag. tip $b$, in psl. nagl. tip $F_{2}$, če se uvršča v psl. nagl. tip c); psl. nagl. tip $\boldsymbol{G}$ - stalni naglas tipa novega akuta na dolgem samoglasniku priponskega obrazila (Dybo 1981; 2000; Dybo - Zamjatina - Nikolajev 1990; 1993; Šekli 2006a: 17-21; 2011).

9 Furlansko gradivo, vzeto iz Pironovega slovarja, je zapisano v skladu s sodobnim furlanskim pravopisom (npr. Madriz - Roseano 2003). 


\section{Jeziki}

alp. rom. alpsko romansko

bav. bavarsko

ben. it. beneško italijansko

furl. furlansko

germ. germansko

got. gotsko

it. knjižno italijansko

lat. latinsko

stfurl. starofurlansko

srvnem. srednjevisokonemško

stvnem. starovisokonemško

\subsubsection{Nabor predstavljenega besedja}

\subsubsection{Neprevzeto netvorjeno besedje}

klin -a m • k'lin 〈Med tuu klínu, Imn klíni, Tmn klí:ne〉 'lesena polkrožna ploščica z dvema luknjama za povezovanje vrvi’ $\square$ SSKJ $\sim$, Plet. $\sim, \mathrm{BdC} \sim$, kat. klen E $<* k l i n-b(\mathrm{a})$

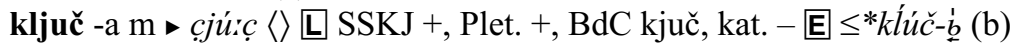

kosa -e ž $\bullet k^{\prime} s \underline{a}\langle\langle\mathrm{\square}+$, kat. kosa $\mathrm{E}<* k o s-a ̀(b)$

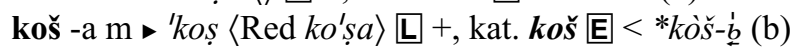

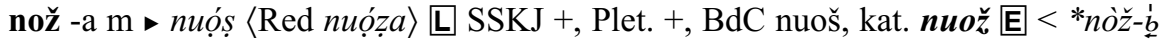
$(\mathrm{b})^{10}$

osla -e ž $\bullet$ ósṣ̣la $\langle$ Ted ọ́sṣlo $\mathbf{\square}$ SSKJ +, Plet. +, BdC -, kat. osla E <*os-(b)l-á (c $\leq \mathrm{b})^{11}$

sito - a $\mathrm{s} \bullet$ șíto $\langle\operatorname{Red}$ síta $\rangle+$, kat. sito $\mathrm{E}<*$ sït-o (a)

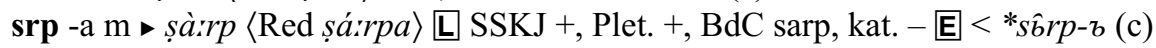

${ }^{10}$ Dolžina v korenu se pri istem leksemu pojavlja tudi v nadiškem narečju - nuóšs, Red nuóža (Šekli, ustno) - in v terskem gradivu Jana Baudouina de Courtenayja, kjer so izpričane tudi oblike s končniškim naglasom in hkrati dvoglasnikom v korenu (Spinozzi

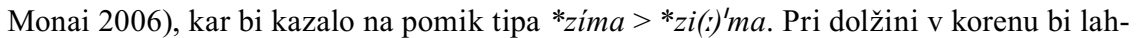
ko šlo za analoško podaljšavo novega akuta v ustreznih oblikah (RMOmn), nato pa za izravnavo. Težavno pri tej razlagi je, da omenjene oblike pri tem leksemu niso pogosto besedilno aktualizirane in so zato manj verjeten model za analogijo. Druga možnost je (sporadična) podaljšava kratkega naglasa ob spirantu, ki ima tipološke vzporednice $\mathrm{v}$ čakavščini in delih štokavščine: čak. (Brač) nõš, Red nōžă, knj. štok. nôž, Red nóža (torej z izravnavo v odvisnih sklonih). Če je do podobnega pojava prišlo v slovenščini, bi pri samostalniku *nǒž vzorec *nóž, Red *no'ža, po izravnavi pa bodisi *nó:ž, Red *nó:ža (na kar kaže stanje v terskem in nadiškem narečju) ali *'nož, Red *no'ža.

${ }^{11}$ Pri leksemu ó́ș̣la je verjetno prišlo do umika naglasa s končnega cirkumflektiranega zloga $v$ Ted in zatem do izravnave, še prej pa do prehoda iz psl. nagl. tipa b v psl. nagl. tip c. V Ied bi sicer pričakovali *oṣla. 
sveča -e ž șvẹéća $\langle$ Ted șvẹ́:ćo $\square$ SSKJ +, Plet. +, BdC sve(j)ća, kat. Imn sveće $<*_{\text {svétá }}(\mathrm{b})^{12}$

stol -a m $\bullet s_{\text {'tọu }}\langle$ Red șto'la tudi stolič 'nizek stol, navadno s tremi nogami' $\square$

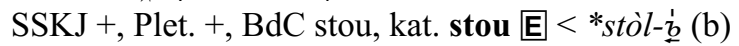

vrata vrat ž $\mathrm{mn} \bullet \mathrm{Imn}$ vrá:ta $\langle\mathrm{Rmn}$ vrá:t $\rangle \mathrm{\square} \mathrm{SSKJ}+$, Plet. +, BdC urata, kat. - $\mathrm{E}$ $<* \operatorname{vort}-\dot{a}(\mathrm{c})$

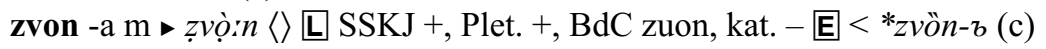

\subsubsection{Neprevzeto tvorjeno besedje}

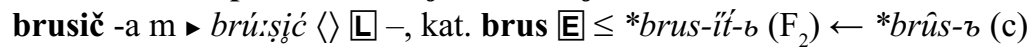

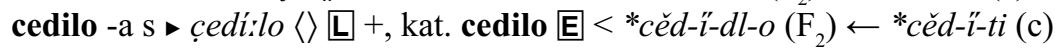

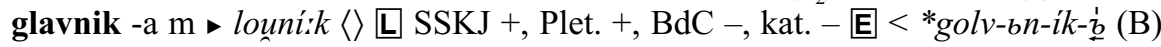
$\leftarrow{ }^{*}$ golv-á (c)

grablje -belj ž mn $\bullet$ Imn rá:bje $\langle$ Red rà:baj〉 $\square$ SSKJ +, Plet. +, BdC grabje, kat. rabje $\mathrm{E}<*^{*}$ gräb-j-e $(\mathrm{A}) \leftarrow{ }^{*}$ gräb-i-ti (a)

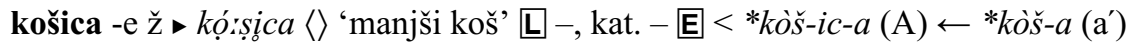

mokarica -e ž $\bullet$ mọ̀kkariga $\langle$ tudi paleta 'velnica, lopatica za zajemanje moke' $\square$ $\mathrm{SSKJ} \sim$, Plet. $\sim, \mathrm{BdC}-$, kat. - 国 $\leq{ }^{*} m \rho k$ - $\dot{a} \dot{r}-i c-a(\mathrm{G}) \leftarrow{ }^{*} m \rho k-\dot{a}(\mathrm{~b})^{13}$

ključavnica -e ž c cjuçà:uniça $\langle\downarrow \mathrm{SSKJ}+$, Plet. +, BdC -, kat. Imn ćjucaunice $\mathrm{E}$

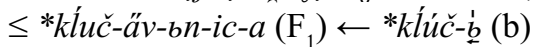

kosišče -a s $\bullet$ koșíșçe \langle\rangle 'držaj pri kosi' $\square+$, kat. kosišče 国 $<*$ *kos-ǐščce $\left(\mathrm{F}_{1}\right) \leftarrow$ *kos-à (b)

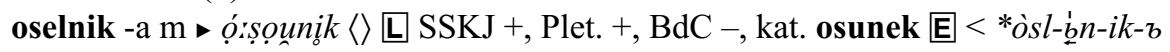
(D) $\leftarrow{ }^{*} o s-(b) l-\dot{a}(\mathrm{~b})^{14}$

poverek -rka $\mathrm{m}>$ povè̀rrak $\langle$ Red povè̀r $r k a\rangle$ 'drog za nošenje vode’ $\square \mathrm{SSKJ}+$, Plet. ,$+ \mathrm{BdC}-$, kat. povirak $\mathrm{E}<{ }^{*}$ po-vĕr - - $k$-ъ $(\mathrm{A})$

preslica -e ž prẹ́rșlica $\langle\backslash \mathrm{SSSJ}+$, Plet. + , BdC -, kat. preslica $<*$ pręd -sl-ic-a (A) $\leftarrow{ }^{*} p r e ̨ ̋ d-s l-o(\mathrm{a}) \leftarrow{ }^{*} p r e ̨ ̋-\emptyset-t i(\mathrm{c}-\mathrm{a})$

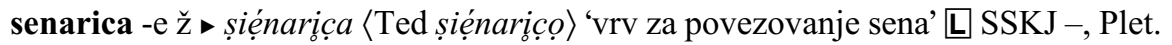

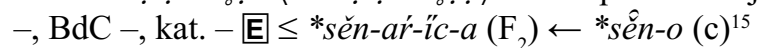

stolič -a $\mathrm{m} \bullet$ ștollić $\langle$ Oed stolíćáan isto kot stol $\square$ SSKJ -, Plet. +, BdC +, kat. - 国 $<*_{\text {stol-itt-b }}\left(\mathrm{F}_{1}\right) \leftarrow{ }^{*}$ stol-i $b(\mathrm{~b})$

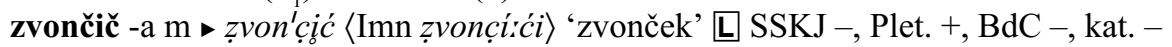
E $<*_{z v o n-b c ̌-i ̈ t-b}(\mathrm{~F}) \leftarrow *_{z v o ̈ n-b}(\mathrm{c})$

žlica -e ž zllíça \langle\rangle$+$, kat. - 国 $\leq * l_{b} z \check{z}-i c c-a(\mathrm{~F}) \leftarrow * l_{b} \check{z} i$

${ }^{12}$ Neregularni enoglasniški refleks v korenu (pričakovali bi **șviẹća) je najverjetneje posledica bližine palatala.

${ }^{13}$ Izpeljanka mọ̀karịça je verjetno tvorjena v času, ko je imel samostalnik *moka po splošnoslovenskem umiku naglasa na prednaglasno dolžino nepremični naglas na osnovi. Podobno velja za izpeljanko șiẹnariça, le da je ta verjetno tvorjena po narečnem umiku s cirkumflektiranega odprtega zloga.

${ }^{14}$ Samostalnik *os(b) la je verjetno šele pozneje prešel v psl. nagl. tip $c$, prej pa se je uvrščal v psl. nagl. tip $b$. V tem času je bil verjetno tvorjen samostalnik *òslı́nikb (psl. besedotvorni nagl. tip $D$ ), saj bi sicer pričakovali **oslbník $\underline{\underline{b}}$ (psl. besedotvorni nagl. tip $B$ ).

${ }^{15}$ Gl. op. 11. 


\subsubsection{Zgodaj prevzeto besedje}

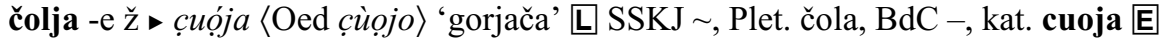
$<{ }^{*} c \grave{o} l-j a\left(\mathrm{a}^{\prime}\right) \leftarrow$ srvnem. zol ${ }^{16}$

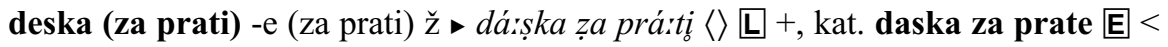
$* d b s k-\dot{a}<* d b s k$-à $\leftarrow$ germ. $*$ diska ${ }^{17}$

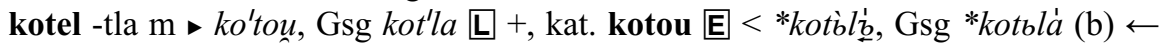
got. *katils

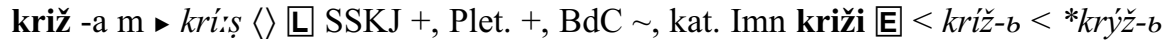
$\leftarrow$ stfurl. *krō̧̌e $\leftarrow$ lat. $\operatorname{CRUCE}(\mathrm{M})$

miza -e ž $\triangleright$ mízza $\langle$ Ted mírzọ $\square+$, kat. Med ta na mizu $\mathrm{E}<*$ mïza $\leftarrow$ stfurl. *mẹa $\leftarrow$ lat. $\operatorname{MenSA}(\mathrm{M})$

skleda -e ž s șkliẹda $\langle$ Red șkliẹde $\rangle$ L SSKJ +, Plet. +, BdC sklieda, kat. sklijede E

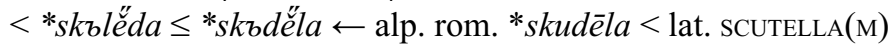

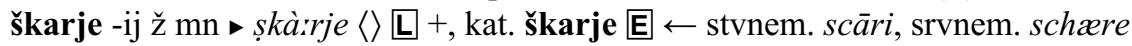

žegnalnik -a $\mathrm{m}$ > zenà:unik $\langle$ Red zenà:unika〉 'kropilnica, posodica za blagoslovljeno vodo' $\square-$, kat. - $\mathrm{E}<*(z ̌ e g n)-a-l-b n-i k$ - $b \leftarrow$ stvnem. sëgan, srvnem. sëgen 'znamenje križa, blagoslov'; stvnem. seganōn, srvnem. sëgenen 'blagosloviti'

\subsubsection{Pozno prevzeto besedje}

ampola -e ž $\bullet$ à:mpola $\langle$ Imn à:mpole 'steklenička' $\square$ SSKJ $\rightarrow$ ampula, Plet. -, $\mathrm{BdC}-$, kat. Imn ampole $\mathrm{E} \leftarrow$ it. ampolla 'steklenička'

armarič -a $\mathrm{m} \vee$ armá:rioć \langle\rangle 'predalnik' $\mathrm{L}-$, kat. armarić $\mathrm{E}<*$ (armar)-it́-b $\leftarrow$ furl. armâr 'predalnik'

broka -e ž $\bullet$ brò̀ka \langle\rangle 'glinen vrč za vino' $\square-$, kat. - E $\leftarrow$ it. brocca 'vrč'

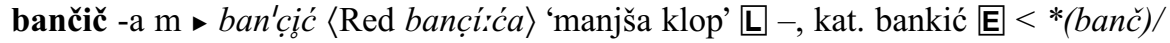
(bank) $-i t$ - $b \leftarrow$ furl. banc 'klop'

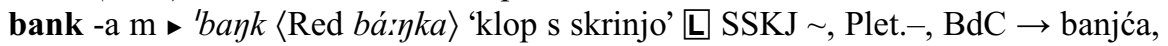
kat. bank $\mathrm{E} \leftarrow$ furl. banc 'klop'

bilanča -e ž $\bullet$ bilà:nća \langle\rangle 'tehtnica' $\square-$, kat. belanza $\mathrm{E} \leftarrow$ furl. belancje 'tehtnica'

${ }^{16}$ Bezlaj (1976: 86) navaja čóla v pomenu 'hlod, deblo, čok, tnalo' (Posočje, gor.) in k temu pridaja čôl 'češarek' (Tolmin) ter čúla 'razklan parobek' (Branica); izvor po njegovem mnenju ni jasen, izhajanje iz novonemškega Zoll, Zollen pa ne pride v poštev, »ker je srvn[em]. zol »carina« dalo sln. col in zol »dolžinska mera« sln. cola« (Bezlaj 1976: 86). Besedo cộl 'parobek' Bezlaj (1976: 67) izvaja iz srvn[em]. zol 'parobek, hlod, tram'. Pri oblikah čóla, čúla in çuója je treba najverjetneje izhajati iz *cóláa, saj vse izkazujejo ustrezne reflekse $* i$, terska in kraška oblika pa tudi zgodnje podaljšave kratkega akuta v nezadnjem zlogu (če je gradivo, navedeno v Bezlaj 1976: 86, naglasno zanesljivo, pri čóla kvaliteta naglašenega vokala kaže na umični naglas, saj bi v obsoškem narečju sicer pričakovali diftong, v gorenjskem pa ozki monoftong). Oblika *čol, iz katere je nastala tolminska oblika, bi lahko bila prevzeta iz srvnem. zol $(<$ pgerm. *tullaz) v nekoliko starejšem obdobju, torej v času, ko se je srvnem. zlitnik izgovarjal šumniško, oblika *čoĺa pa tvorjena naknadno s pripono *-ja. Alternativno bi lahko šlo za prevzem z vključitvijo v $a$-jevsko sklanjatev, pri čemer je $* \dot{l}$ slovenski substitut srvnem. srednjega $l$.

${ }^{17}$ Ker naglasni umik na prednaglasni polglasnik v narečju ni regularno izvršen, gre pri korenskem naglasu pri tipu dásska najverjetneje za izravnavo po Ted, kjer je prišlo do umika cirkumfleksa s končnega zloga. 


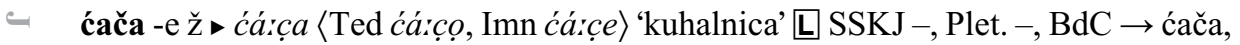
kat. Imn ćace $\mathrm{E} \leftarrow$ furl. cjace 'kuhalnica'

ćandreja -e ž • ćandrè:ja 〈Ted ćandrè:jọ, Imn ćandrè̀je〉 ‘stol' L SSKJ -, Plet. -, $\mathrm{BdC}+$, kat. ćjandrea $\mathrm{E} \leftarrow$ furl. cja(n)drèe 'stol'

falčet -a $\mathrm{m} \vee$ fal'çet $\langle$ Red falçe'ta $\rangle$ 'kosa' $\mathrm{L}$ SSKJ -, Plet. -, BdC +, kat. falčet $\mathrm{E} \leftarrow$ furl. falcèt 'kosa'

gerdz -a m • gérrç $\langle$ Red gé:rza〉 'gradaše' $\square$ SSKJ -, Plet. -, BdC +, kat. gerz $\mathrm{E} \leftarrow$ ben. it. garzo 'gradaše'

grac -a $\mathrm{m} \vee$ 'raç $\langle\mathrm{Imn}$ rácci 'strgalnik' $\mathrm{L}$-, Imn raci $\mathrm{E} \leftarrow$ furl. mn grats (ed grat) 'strgalnik'

kafetjera -e ž $\bullet$ kafetjérra 〈〉 'priprava za kuhanje kave' $\square-$, kat. - E $\longleftarrow$ it. caffettiera 'priprava za kuhanje kave'

kamba -e ž $\bullet$ ká:mba \langle\rangle 'ukrivljena lesena palica pri jarmu’ $\square$ SSKJ +, Plet. +, BdC -, kat. kamba $\mathrm{E} \leftarrow$ ben. it. camba $\leftarrow$ bav. kampa

karatel -a $\mathrm{m} \bullet$ kara'tel $\langle\mathrm{Imn}$ karatẹ́:li〉 'sod za vino’ $\mathrm{L} \mathrm{SSKJ}-$, Plet. -, BdC +, kat. karatel $\mathrm{E} \leftarrow$ ben. it. caratelo 'sod'

karatelič -a m $\bullet\langle$ Imn karatẹ:lići 'manjši sod' $\mathbf{\square}-$, kat. - E $<*($ karatel)-it́-b $\leftarrow$ ben. it. caratelo 'sod'

korjan -a m • korjá:n 〈prid. Imn korjá:navì 'usnje' — $\mathrm{SSKJ}$-, Plet. -, BdC +, kat. - E $\leftarrow$ furl. coreàn 'usnje'

kračula -e ž $\bullet$ kràrçula 'raglja' $\square$-, kat. kračula E $\leftarrow$ furl. craçule 'raglja'

lučernja -e ž lucérrńa 〈Red lučérrne, Ted lučérnno, Imn lučé:rńe〉 'oljna svetilka' $\square$ SSKJ -, Plet. $\rightarrow$ lučerna, BdC -, kat. - E $\leftarrow$ furl. lucergne

makinja (za šivati) -e ž mà:kińa za șivá:ti \langle\rangle '(šivalni) stroj’ $\square$-, kat. makinja za šivate $\mathrm{E} \leftarrow$ furl. machigne 'stroj, naprava'

meženin -a m $\bullet$ meẓe'nin 'mlinček za kavo' $\square-$, kat. meženin E $\leftarrow$ furl. masanin 'mlinček'

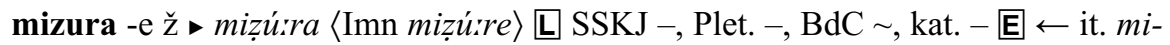
sura 'merica'

orloj -a m $\bullet$ or'loj \langle\rangle 'ura' $\square$ SSKJ - , Plet. -, BdC +, kat. orloj E $\leftarrow$ furl. orloi 'ura' paleta -e ž palé:ta 〈Ted palẹ́:to〉 isto kot mokarica $\square \mathrm{SSKJ} \sim$, Plet. , BdC -, kat. paleta $\mathrm{E} \leftarrow$ furl. palete, it. paletta 'lopatica'

peza -e ž $\vee$ pèrza \langle\rangle 'tehtnica' $\square-$, kat. - E $\leftarrow$ ben. it., it. pesa 'tehtnica' pinja -e ž pí:ńa $\langle$ Imn pí:ne $\rangle \mathrm{\square}+$, kat. pinja $\mathrm{E} \leftarrow$ furl. pigne 'pinja' sapin -a $m \bullet \operatorname{sa} a^{\prime} \operatorname{pin}_{o}\langle\rangle$ 'cepin' $\square-$, kat. sapin $\mathrm{E} \leftarrow$ furl. sapin 'cepin' seget -a $m \bullet s e^{\prime}$ get \langle\rangle 'žaga' $\square-$, kat. Imn segeti $\mathrm{E} \leftarrow$ furl. seghet 'žaga'

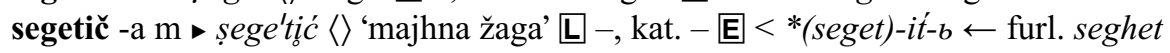
'žaga'

sejun -a m • șejù:n $\langle$ Imn sejù:nì ‘žaga' $\square$-, kat. seun $E \leftarrow$ furl. seon 'žaga'

stiralnik -a m • știrá:unik \langle\rangle 'likalnik' $\square-$, kat. steraunek $\mathrm{E}<*($ stir-a)-l-bn-ik-b $\leftarrow$ it. stirare 'likati'

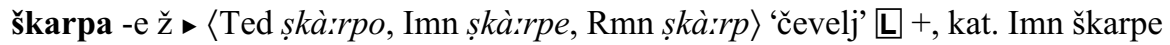
E $\leftarrow$ it. scarpa 'čevelj'

škarpeta -e ž $\triangleright\langle$ Imn șkarpe'te ‘čevelj’ $\square-$, kat. - E $\leftarrow$ furl. scarpete $\leftarrow$ it. scarpa 'čevelj' 
špinjak -a m $\triangleright$ spìñak \langle\rangle 'sveder' $\square$-, kat. špinjak $\mathrm{E} \leftarrow$ nejasno, morda furl.

*spignac 'sveder'

tavla -e ž $•$ tá:ula \langle\rangle 'miza' $\mathbf{L}$ SSKJ -, Plet. -, BdC +, kat. - E $\leftarrow$ furl. taule 'miza' tavlica -e ž $\vee$ tá:uliça \langle\rangle 'majhna miza' $\square-$, kat. - E $<*$ (taul)-ic-a $\leftarrow$ furl. taule zvelja -e ž zvé:lja 〈〉 'budilka' $\square-$, kat. zvelja $\mathrm{E} \leftarrow$ it. sveglia 'budilka'

\section{$4 \quad$ Sklep}

Iz navedenega gradiva je videti, da novejše prevzeto besedje romanskega izvora po številu močno prevladuje, izpodriva pa tudi starejše neprevzeto besedje, npr. ćandrè:ja 'stol' $\leftarrow$ furl. cjandree (ș'tou, șto'lić se uporablja v pomenu 'majhen stol, pručka'); ta:ula 'miza' $\leftarrow$ furl. taule (poleg starejšega mízza); fal'çet 'kosa' $\leftarrow$ furl. falcet (poleg starejšega $k o ’ s ̣ a$ ). Iz številnih osnov, prevzetih tudi v novejšem času, se produktivno tvorijo izpeljanke z neprevzetimi obrazili: ban'çić 'majhna klop' < $*($ banč $) /($ bank $)-i t$-b $\leftarrow$ furl. banc 'klop'; armásrićc 'omarica' <*(armar)-it́-b $\leftarrow$ furl. armâr 'predalnik'; știrá:unik 'likalnik' <*(stir-a)-l-bn-ik-b $\leftarrow$ it. stirare 'likati'. Zaradi intenzivnega jezikovnega stika s stičnimi romanskimi idiomi in postopnega upada jezikovne kompetence govorcev slovenskega narečja skozi čas je stanje do neke mere pričakovano.

\section{Literatura}

Bezlaj 1976-2007 = France Bezlaj, Etimološki slovar slovenskega jezika 1-5, avtorji gesel France Bezlaj - Marko Snoj - Metka Furlan, Ljubljana: SAZU oz. ZRC SAZU (izd.) - Mladinska knjiga oz. Založba ZRC, ZRC SAZU, 1976-2007.

Boerio = Giuseppe Boerio, Dizionario del dialetto veneziano, Venezia: Giovanni Cecchini, 1867.

Cernetig - Negro $2009=$ Mi smo tu ... tuka, ... izdë, ... kle, ... tle, ur. Marina Cernetig - Luigia Negro, Špeter: Inštitut za slovensko kulturo, 2009.

Dapit 1995 = Roberto Dapit, La Slavia Friulana: lingue e culture: Resia, Torre, Natisone: bibliografia ragionata $=$ Beneška Slovenija: jezik in kultura: Rezija, Ter, Nadiža: kritična bibliografija, Čedad - Špeter: Kulturno društvo Ivan Trinko - Zadruga Lipa, 1995.

Dardano - Trifone 2001 = Maurizio Dardano - Pietro Trifone, Grammatica italiana con nozioni di linguistica, Bologna: Zanichelli, 2001.

Del Medico 2004 = Dino Del Medico, Censimento oggetti: museo etnografico, Comune Lusevera, 2004. (Tipkopis.)

Dybo 1981 = Владимир Антонович Дыбо, Славяанкая акиентология, Москва: Наука, 1981.

Dybo 2000 = Владимир Антонович Дыбо, Морфонологизованные парадигматические акцентные системы: типология и генезис, Москва: Яазыки русской культуры, 2000. 
Dybo - Zamjatina - Nikolajev 1990 = Владимир Антонович Дыбо - Галина Игоревна Замятина - Сергей Львович Николаев, Основы славянской акиентологии, Москва: Наука, 1990.

Dybo - Zamjatina - Nikolajev 1993 = Владимир Антонович Дыбо - Галина Игоревна Замятина - Сергей Львович Николаев, Основы славянской акиентологии: словарь, Москва: Наука, 1993.

Erat $2008=$ Janez Erat, Furlansko-slovenski slovar $=$ Il dizionari furlan-sloven, $2008\langle\mathrm{http}: / /$ janezerat.blogspot.com/, dostop 3. 11. 2013〉.

Ježovnik 2012 = Janoš Ježovnik, Narečna poezija Renata Quaglie v prevodih Marka Kravosa: diplomsko delo, Ljubljana: Oddelek za primerjalno književnost in literarno teorijo, 2012.

Kacin Wohinz - Pirjevec 2000 = Milica Kacin Wohinz - Jože Pirjevec, Zgodovina Slovencev v Italiji 1866-2000, Ljubljana: Nova revija, 2000.

Kenda Jež 2007 = Karmen Kenda Jež, Shranili smo jih v bančah: slovarski prispevek $k$ poznavanju oblačilne kulture $v$ Kanalski dolini $=$ contributo lessicale alla conoscenza dell'abbigliamento in Val Canale, Ukve - Ljubljana: S. K. S. Planika Kanalska dolina - Slori - Inštitut za slovenski jezik Frana Ramovša, 2007.

Kos idr. 1974 = Milko Kos - Lavo Čermelj - Bogo Grafenauer - Janko Jeri - Gorazd Kušej, Slovenci v Italiji včeraj in danes, Trst: Založništvo tržaškega tiska, 1974.

Križnar $2006=$ Naško Križnar, Etnografski muzej v mlekarni, v: Terska dolina $=$ Alta Val Torre = Val de Tor: Terska dolina $v$ besedi, sliki in pesmi Viljema Černa, ur. Milena Kožuh, Celje: Celjska Mohorjeva družba - Gorica: Goriška Mohorjeva družba, 2006, 239-242.

Logar 1976 = Tine Logar, Slovenska narečja, Ljubljana: Mladinska knjiga, 1976.

Madriz - Roseano 2003 = Anna Madriz - Paolo Roseano, Scrivere in friulano, Udine: Società Filologica Friulana, 2003.

Makuc 2013 = Neva Makuc, Sclavi, schiavi in podobni izrazi v miselnem svetu novoveških avtorjev, Škrabčevi dnevi 8: zbornik povzetkov simpozija 2013, Nova Gorica, 2013, 11.

Marušič $2006=$ Branko Marušič, Pregled zgodovine terskih Slovencev, v: Terska dolina $=$ Alta Val Torre $=$ Val de Tor: Terska dolina $v$ besedi, sliki in pesmi Viljema Černa, ur. Milena Kožuh, Celje: Celjska Mohorjeva družba - Gorica: Goriška Mohorjeva družba, 2006, 55-61.

Merkù 2006 = Pavle Merkù, Krajevno imenoslovje na slovenskem zahodu, ur. Metka Furlan - Silvo Torkar, Ljubljana: Založba ZRC, ZRC SAZU, 2006.

Pirona $=$ Giulio Andrea Pirona, Ercole Carletti, Giovanni Battista Corgnali, Il nuovo Pirona. Vocabolario friulano, Udine: Società filologica Friulana, 1992.

Pleteršnik (Plet.) = Maks Pleteršnik, Pleteršnikov Slovensko-nemški slovar: spletna izdaja, Ljubljana: Znanstvenoraziskovalni center Slovenske akademije znanosti in umetnosti, Inštitut za slovenski jezik Frana Ramovša ZRC SAZU, $2010\langle$ http://bos.zrc-sazu.si/pletersnik.html〉.

Ramovš 1935 = Fran Ramovš, Historična gramatika slovenskega jezika VII: dialekti, Ljubljana: Učiteljska tiskarna, 1935. 
Rigler 1963 = Jakob Rigler, Pregled osnovnih razvojnih etap v slovenskem vokalizmu, v: Jakob Rigler, Zbrani spisi 1: jezikovnozgodovinske in dialektološke razprave, ur. Vera Smole, Ljubljana: Inštitut za slovenski jezik Frana Ramovša ZRC SAZU, 2001, 13-57.

Ruttar 2006 = Riccardo Ruttar, Lusevera - Bardo, Il luogo e la sua gente - Una comunità in pericolo, v: Terska dolina $=$ Alta Val Torre $=$ Val de Tor: Terska dolina v besedi, sliki in pesmi Viljema Černa, ur. Milena Kožuh, Celje: Celjska Mohorjeva družba - Gorica: Goriška Mohorjeva družba, 2006, 87-90.

Skubic 1997 = Mitja Skubic, Romanske jezikovne prvine na zahodni slovenski jezikovni meji, Ljubljana: Znanstveni inštitut Filozofske fakultete, 1997.

Skubic 2002 = Mitja Skubic, Romanski jeziki, Ljubljana: Filozofska fakulteta Univerze v Ljubljani, Oddelek za romanske jezike in književnosti, 2002.

Skubic 2006 = Mitja Skubic, Slovenske jezikovne prvine v obsoški furlanščini, Ljubljana: Znanstvenoraziskovalni inštitut Filozofske fakultete, 2006.

SSKJ = Slovar slovenskega knjižnega jezika, Ljubljana: DZS, 2005.

Snoj 2009 = Marko Snoj, Slovenski etimološki slovar, Ljubljana: Modrijan, 2009.

Spinozzi Monai 2009 (BdC) = Liliana Spinozzi Monai, Il Glossario del dialetto del Torre di Jan Baudouin de Courtenay, Udine: Consorzio Universitario del Friuli, 2009.

Stang 1957 = Christian Stang, Slavonic accentuation, Oslo, 1957.

Striedter-Temps 1963 = Hildegard Striedter-Temps, Deutsche Lehnwörter im Slovenischen, Berlin: Osteuropa-Institut - Wiesbaden: Otto Harrassowitz, 1963.

Šekli 2006a = Matej Šekli, Ledinska imena v kraju Livek in njegovi okolici: doktorska disertacija, Ljubljana, 2006.

Šekli 2006b = Matej Šekli, Tersko narečje v kraju Subid, v: Terska dolina $=$ Alta Val Torre = Val de Tor: Terska dolina v besedi, sliki in pesmi Viljema Černa, ur. Milena Kožuh, Celje: Celjska Mohorjeva družba - Gorica: Goriška Mohorjeva družba, 2006, 161-173.

Šekli 2009 = Matej Šekli, Merila za določanje mej med slovenskimi narečji in podnarečji, v: Slovenska narečja med sistemom in rabo, ur. Vera Smole, Ljubljana: Znanstvena založba Filozofske fakultete, 2009.

Šekli 2011 = Matej Šekli, Predzgodovina praslovanskega naglasnega sistema v luči moskovske naglasoslovne šole, Jezikoslovni zapiski 17 (2011), št. 2, 7-40.

Šekli 2014 = Matej Šekli, Metodologija določanja plasti mlajših romanizmov v slovenščini, Jezikoslovni zapiski 19 (2013), št. 2, 291-315.

Šlenc = Sergij Šlenc, Veliki italijansko-slovenski slovar: elektronska izdaja, Ljubljana: DZS, ${ }^{2} 2008$.

Weiss 1998 = Peter Weiss, Slovar govorov Zadrečke doline med Gornjim gradom in Nazarjami: poskusni zvezek: A-H, Ljubljana: ZRC SAZU, Založba ZRC, 1998 (Slovarji).

Weiss 2006 = Peter Weiss, Besedje na kolesu v (slovenskem) narečnem slovarju z etimologijami, v: Diahronija in sinhronija v dialektoloških raziskavah, ur. Mihaela Koletnik - Vera Smole, Maribor: Slavistično društvo, 2006 (Zora 41), 328-335. 
Zingarelli = Nicola Zingarelli, Lo Zingarelli: vocabolario della lingua italiana, Bologna: Zanichelli, 2007.

Zuljan Kumar 2010 = Danila Zuljan Kumar, Subiške pripovedi z jezikovnega stališča, v: Bruna Balloch, Mlada lipa: pravace domah narete, Čedad: Kulturno društvo Ivan Trinko, 2010.

\title{
The Origin of Terms for Tools and Household Instruments in the Terski Dialect
}

\begin{abstract}
Summary
This article presents dialect names for tools and instruments displayed in the ethnographic museum in the village of Lusevera (Sln. Bardo) in the Torre Valley. The local dialect of Bardo is a part of the Terski dialect, which is spoken in the valley of the Torre River and its tributaries in the Province of Udine, part of the autonomous Friuli-Venezia Giulia region of Italy. According to genetic linguistics, it belongs to the Venetian-Karst dialectal base and, if the auditory impression and recent developments are taken into account, it belongs to the Littoral dialect group. An uncommon phonetic innovation in the dialect that is typical of the Bardo dialect is elision of the phoneme $g$; this phoneme only appears in recent loanwords. Based on their origin, words in the Bardo dialect can be divided into native and borrowed. Native words are roots and compounds. Loanwords were borrowed early, either in the late Common Slavic period or later, but before the language came into strong contact with the Romance adstrata, and late, borrowed recently especially from Friulian, Venetian Italian, and since 1866 from standard Italian as well. Loanwords represent a large majority of the words analyzed and are replacing old native names as well. Many roots, both those borrowed early as well as recently, serve as a basis for productive derivation with native affixes.
\end{abstract}

